\title{
Manager as a leader in implementing strategic changes at the enterprises
}

\author{
Elena Korneeva \\ Department of Management \\ Volga Region State University of Service \\ Gagarina St., 4, 445017 Togliatti \\ Russian Federation \\ e-mail: korneeva1207@yandex.ru \\ Raisa Krayneva \\ Department of Management \\ Volga Region State University of Service \\ Gagarina St., 4, 445017 Togliatti \\ Russian Federation \\ e-mail: raisa-krayneva@yandex.ru \\ Alexandr Platitsyn \\ Department of Management \\ Volga Region State University of Service \\ Gagarina St., 4, 445017 Togliatti \\ Russian Federation \\ e-mail: platitsyna.natalia@yandex.ru
}

\begin{abstract}
Readiness and ability to adapt flexibly to the dynamic environment, i.e. to be susceptible to the changes, define the effectiveness and success of any activity of the person, the organization, society in many respects. Management of changes performs the function of the catalyst for development and improvement of management processes. Therefore a subsystem of change management process is included in the enterprise management system along with other types of administrative activity, such as strategic management, management of human resources (MHR), financial management and etc. as the changes are carried out in all functional areas of the enterprise during competition for the leading positions in the market segment.

There is a necessity for consecutive and multilevel management of changes during implementation of the transformations. Article opens manager's role - as the leader operating changes at the enterprise; the stages of management of changes, including the preparation, introduction and fixing of the received results of the transformations. In the course of stage passing there is the feedback providing the correction of changes and accumulation of positive experience of transformation implementation at the enterprise is provided. Moreover, the interrelation of organizational strategy and the strategy of human-resource management for the purpose of non-stop monitoring of the staff relation to the transformations is also considered.
\end{abstract}

\section{Introduction}

Strategic changes in the organization are followed by the considerable resistance of staff to the changes as affect the status and the interests of each employee. Various authors offered the general recommendations on the management of resistance for the heads (Sisson 1993; Martell and Carroll 1995; Purcell 1999; Alekhina 2004; Duck 2002; Erokhin 2002), as follows:

- to involve the maximum number of employees in transformation process that will provide its openness and will reduce the team fear of uncertainty;

- to think over in advance and to explain to the staff the system of moral and material encouragement for additional participation in activity to increase organization efficiency;

- to create an open information environment that is to hold systematically the planning meetings, team meetings devoted only to one issue - the organizational development. It is possible to publish the corporate newspaper, single information leaflets, etc.;

- to carry out the internal and external PR campaign showing advantages, potential benefits and possibilities of the carried-out changes;

- to form gradually but persistently the new innovative culture and ideology of the organization. 
Let us mark out the basic principles of human-resource management in the terms of transformational changes. Some of them are crucial for the performance of the business companies (see e.g. Korchagin et al. 2015; Narkunienè and Ulbinaitė 2018; or Plenkina et al. 2018):

- $\quad$ realization necessary, useful and favorable transformations for the organization and staff;

- $\quad$ stage-by-stage implementation of changes;

- readiness for evolutionary and revolutionary changes;

- formation of adequate strategy for management of resistance;

- involvement of all employees in process;

- identification of problems could not be eliminated.

In addition, it appears that the low effectiveness of MHR strategy can be caused by the following factors:

- low level of organizational culture of the enterprise;

- low level of coverage of the organization staff by the measures for management of changes;

- employees' insufficient motivation for training;

- insufficient resource to provide the actions for management of changes;

- $\quad$ authoritative management style.

\section{The approaches and methods for overcoming the resistance to changes}

Most of the heads often use a possibility of staff informing as the main approach to the management of changes (Duck 2002). The approach called "fair bargaining" "recognizes inevitability of resistance and stimulates to the creation of the atmosphere disposing to honest communication", solves the following problems of management of resistance:

- recognizing inevitability of resistance therefore acts in relation to the resistance honestly and consistently;

- reflecting the fact that the resistance can be expressed openly or hidden and giving the arguments in favor of the open resistance due to the problems emerged on a surface;

- warning that it is possibly awkward for the people to express the true reasons of resistance and stimulating creation of the atmosphere disposing to honest communication.

In the West, many experts think that heads and managers forget the most important principle of management of changes: the organizations are not changed; people are changed (Strielkowski et al. 2016). Therefore, during the transformations and introduction of long changes the role of the head-administrator is transformed to the leading manager, especially carefully it is necessary to transfer administrative initiatives to participation of each worker whom these changes will concern (Kleiner 2007; Korchagin et al. 2015; Moskalenko and Yevsieieva 2015; Ćábelková et al. 2015; or Krayneva et al. 2017). The leaders of transformations have to be sure that all participants understand and support these changes as an opportunity for updating and improvement (Niño-Amézquita et al. 2017).

Table 1. Policy strokes of overcoming resistance to the changes

\begin{tabular}{|l|l|}
\hline \multicolumn{1}{|c|}{ Approach } & \multicolumn{1}{c|}{ Situations adequate to its application } \\
\hline $\begin{array}{l}\text { Communications, } \\
\text { programs of training }\end{array}$ & $\begin{array}{l}\text { Changes have technical character } \\
\text { Understanding of nature of changes assumes obtaining exact } \\
\text { information by its users and its independent analysis }\end{array}$ \\
\hline Participation in changes & $\begin{array}{l}\text { The users of changes seek for participation in transformation process } \\
\text { Development of change demands additional information from other } \\
\text { sources } \\
\text { The users possess the resources for counteraction }\end{array}$ \\
\hline Negotiations & $\begin{array}{l}\text { The group has a resistance potential } \\
\text { The changes cause damage to the interests of group }\end{array}$ \\
\hline Enforcement & $\begin{array}{l}\text { In a crisis situation the initiators of change have necessary authority } \\
\text { power, all other methods were inefficient }\end{array}$ \\
\hline Top-management support & $\begin{array}{l}\text { Changes affect several departments or assume resource redistribution } \\
\text { The users of changes are not sure of their legitimacy }\end{array}$ \\
\hline
\end{tabular}

Source: Milner (2006) 
The result generalization of researches on overcoming the resistance to the changes allowed Milner (2006) to allocate a number of the most effective policy strokes (Table 1 above). In addition, Ansoff (1999) allocates four types of management of changes:

- compulsory management of changes;

- crisis management;

- $\quad$ adaptive changes;

- a method of the operated resistance.

The compulsory method of carrying out the changes assumes use of authority power for overcoming the resistance. This method is applied in the terms of time deficiency, its shortcoming is the growing resistance and social tension. Crisis management is aimed at acceptance of precautionary measures for resistance decrease and formation of support of changes. The method of adaptive changes assumes carrying out minor changes during the long period. The resistance is overcome with compromises, there is a strong motivation to implement the changes. Finally, the operated resistance is the method allowing implement the changes with a different speed, combining actions for decrease in resistance depending on the requirements of the external environment.

\section{$3 \quad$ Strategy for prophylaxis and overcoming the resistance to changes}

The strategy of a preventive prophylaxis and overcoming the resistance is developed as the most important condition to implement the strategy of changes (Table 2).

Table 2. Strategy content to prevent prophylaxis and overcome the resistance

\begin{tabular}{|c|c|c|}
\hline Strategy elements & Preventive prophylaxis & Resistance overcoming \\
\hline Purpose & $\begin{array}{l}\text { - Ensuring perception of changes } \\
\text {-Formation of employees' } \\
\text { devotion }\end{array}$ & $\begin{array}{l}\text { - Ensuring an active participation in change } \\
\text { realization } \\
\text { - Loyalty increase of labor team }\end{array}$ \\
\hline $\begin{array}{l}\text { Dialogue } \\
\text { group }\end{array}$ & $\begin{array}{l}\text { - Working group } \\
\text { - Labor team }\end{array}$ & $\begin{array}{l}\text { - "Observers" } \\
\text { - "Supporters of resistance" } \\
\text { - "Activists of resistance" }\end{array}$ \\
\hline Methods & $\begin{array}{l}\text { Gaining "the hearts and minds" } \\
\text { - Analytical }\end{array}$ & $\begin{array}{l}\text { - Negotiations } \\
\text { - Directive }\end{array}$ \\
\hline $\begin{array}{l}\text { Tools of } \\
\text { realization }\end{array}$ & $\begin{array}{l}\text { - Internal communications: } \\
\text { informing, explanation of an } \\
\text { essence of changes, increase of } \\
\text { trust to the head and the working } \\
\text { group } \\
\text { - Positive non-material stimulus } \\
\text { and motives } \\
\text { - Involvement in the process of } \\
\text { transformations }\end{array}$ & $\begin{array}{l}\text { - Training with obligatory preliminary } \\
\text { informing } \\
\text { - Communications of the head and a dialogue } \\
\text { group } \\
\text { - Communications of labour and dialogue } \\
\text { groups } \\
\text { - Involvement and coercion to participation by } \\
\text { means of positive and negative non-material } \\
\text { stimulation and motivation }\end{array}$ \\
\hline Manager's role & $\begin{array}{l}\text { - Leadership } \\
\text { - Choice of measures for positive } \\
\text { motivation }\end{array}$ & $\begin{array}{l}\text { - Mentoring } \\
\text { - Choice of measures for positive and negative } \\
\text { motivation, administrative influence }\end{array}$ \\
\hline
\end{tabular}

Source: Korneeva and Gerasimov (2008)

It is expedient to carry out the strategy of a preventive prophylaxis before the emergence of negative reaction of the enterprise staff until the doubts, a fear of uncertainty, actions of informal groups gain the strength.

Making decision on prevention of resistance is carried out by the head and his/her management team responsible for introduction of changes. The realization of strategy of a preventive prophylaxis is carried out at a stage of preparation of changes for the purpose of anticipatory impact on resistance of employees (Korneeva 2016).

The actions for prevention and overcoming the resistance to changes demand the corresponding resource providing. At the choice of measures for management of changes it is expedient to take into account the experience of implementation of programs for preparation and development of staff, support of the management, informing on transformations at the enterprises. Their main shortcoming can be considered the fact that they assume presence at initiators of changes of rather long time and considerable financial means. At the same time the efficiency of such measures, as a rule, is high. Coercive measures yield fast results. However, their long-term 
consequences can be negative: resistance to the imposed change increases again, the fear and uncertainty of a situation become constant satellites of transformations at the enterprise.

It is expedient to include the recommendations on realizing a role of the head as the leading mentor in the structure of strategy for overcoming resistance. The following algorithm of the choice of recommendations is offered:

1. Acquaintance with the data of assessment of readiness, desirability and ability of the enterprise to the changes in a form of data presentation of assessment of staff relation to the changes.

2. The choice of the option corresponding to the data of assessment according to Table 3 .

3. Formulation of conclusions on a role of the head in the course of realization of MHR strategy.

Table 3. Typology of situations of readiness, ability and desirability of changes

\begin{tabular}{|c|c|c|c|c|}
\hline $\begin{array}{l}\text { Choice } \\
\text { Criteria }\end{array}$ & $\begin{array}{c}\text { ORCh }>0 \\
\text { DCh }>0\end{array}$ & $\begin{array}{c}\text { ORCh }>0 \\
\text { DCh }<0\end{array}$ & $\begin{array}{c}\text { ORCh }<0 \\
\text { DCh }>0\end{array}$ & $\begin{array}{c}\text { ORCh }<0 \\
\text { DCh }<0\end{array}$ \\
\hline $\mathrm{ACh}>0$ & $\begin{array}{l}\text { Variant 1 } \\
\text { Staff members want to } \\
\text { carry out } \\
\text { transformations. They } \\
\text { are sure of ability of the } \\
\text { management to bring } \\
\text { the changes to the } \\
\text { planned purposes and } \\
\text { readiness of the } \\
\text { organization for } \\
\text { transformations. In } \\
\text { these conditions the } \\
\text { employees expect from } \\
\text { the head a } \\
\text { professionalism, ability } \\
\text { to formulate strategic } \\
\text { objectives and to reach } \\
\text { them. The head has to } \\
\text { strengthen support of } \\
\text { changes by staff } \\
\text { participation in } \\
\text { realization of strategy of } \\
\text { a preventive } \\
\text { prophylaxis. }\end{array}$ & $\begin{array}{l}\text { Variant } 2 \\
\text { The employees want } \\
\text { to carry out the } \\
\text { transformations and } \\
\text { consider that the } \\
\text { organization is ready } \\
\text { for changes. At the } \\
\text { same time, they are } \\
\text { skeptical about } \\
\text { management ability to } \\
\text { bring the changes to } \\
\text { the planned goals. } \\
\text { The leader has to } \\
\text { make efforts for } \\
\text { informing the team } \\
\text { about the purposes, } \\
\text { intermediate results, } \\
\text { progress, problems } \\
\text { and solutions. The } \\
\text { emphasis is placed on } \\
\text { informing on the role } \\
\text { of the leader in the } \\
\text { course of } \\
\text { transformations. }\end{array}$ & $\begin{array}{l}\text { Variant } 3 \\
\text { The staff of the } \\
\text { organization wants } \\
\text { to carry out } \\
\text { transformations and } \\
\text { is sure of } \\
\text { management ability } \\
\text { to bring the changes } \\
\text { to the planned } \\
\text { goals. At the same } \\
\text { time, they consider } \\
\text { that the organization } \\
\text { isn't quite ready for } \\
\text { large-scale changes. } \\
\text { The head has to } \\
\text { concentrate on the } \\
\text { process of the } \\
\text { organization of staff } \\
\text { development and its } \\
\text { training, employees' } \\
\text { support and the } \\
\text { preparation them to } \\
\text { implement the } \\
\text { changes. }\end{array}$ & $\begin{array}{l}\text { Variant } 4 \\
\text { The employees want } \\
\text { to carry out the } \\
\text { transformations but } \\
\text { consider that the } \\
\text { organization isn't } \\
\text { ready for them. } \\
\text { They are skeptical } \\
\text { about management } \\
\text { ability to bring the } \\
\text { changes to the } \\
\text { planned goals. The } \\
\text { head has to make to } \\
\text { focus his/her } \\
\text { attention to } \\
\text { leadership, personal } \\
\text { participation in } \\
\text { transformational } \\
\text { process, informing, } \\
\text { support and to the } \\
\text { involvement of staff } \\
\text { to participate in } \\
\text { changes. }\end{array}$ \\
\hline $\mathrm{ACh}<0$ & $\begin{array}{l}\text { Variant } 5 \\
\text { The employees are } \\
\text { rather competent and } \\
\text { can but don't want to } \\
\text { work in new conditions. } \\
\text { At the same time they } \\
\text { are sure of ability of the } \\
\text { management to achieve } \\
\text { the objectives and } \\
\text { consider that the } \\
\text { organization is ready for } \\
\text { transformations. } \\
\text { The head's task -is to } \\
\text { increase motivation of } \\
\text { employees, having } \\
\text { convinced them of } \\
\text { necessity and } \\
\text { expediency of changes, } \\
\text { to hold the negotiations } \\
\text { with "observers" and } \\
\text { "supporters of } \\
\text { resistance". Special } \\
\text { programs of training of } \\
\text { employees are } \\
\text { necessary. }\end{array}$ & $\begin{array}{l}\text { Variant } 6 \\
\text { The employees are } \\
\text { rather competent and } \\
\text { can but don't want to } \\
\text { work in new } \\
\text { conditions. They } \\
\text { consider that the } \\
\text { organization in } \\
\text { general is ready for } \\
\text { transformations but } \\
\text { aren't sure of ability } \\
\text { of the management to } \\
\text { achieve the } \\
\text { objectives. The head's } \\
\text { task - is to increase } \\
\text { the level of } \\
\text { motivation and to } \\
\text { inform the team on } \\
\text { the purposes, results, } \\
\text { problems and ways of } \\
\text { their overcoming. The } \\
\text { head has to convince } \\
\text { the employees of } \\
\text { correctness of strategy } \\
\text { of changes or resort to } \\
\text { coercion. }\end{array}$ & $\begin{array}{l}\text { Variant } 7 \\
\text { The staff of the } \\
\text { organization doesn't } \\
\text { show willingness to } \\
\text { work in new } \\
\text { conditions. They } \\
\text { consider that changes } \\
\text { aren't prepared but } \\
\text { believe in ability of } \\
\text { the management to } \\
\text { carry out the changes. } \\
\text { The head's task - is to } \\
\text { increase employees' } \\
\text { motivation and to } \\
\text { explain inevitability } \\
\text { of changes, in the } \\
\text { absence of effect the } \\
\text { head will be forced } \\
\text { coercion. }\end{array}$ & $\begin{array}{c}\text { Variant } 8 \\
\text { The staff of the } \\
\text { organization doesn't } \\
\text { show willingness to } \\
\text { work in new } \\
\text { conditions. They } \\
\text { consider that changes } \\
\text { aren't prepared but } \\
\text { believe in ability of } \\
\text { the management to } \\
\text { carry out the changes. } \\
\text { The resistance to } \\
\text { changes in such } \\
\text { organization is } \\
\text { especially } \\
\text { considerable. The role } \\
\text { of the head comes } \\
\text { down to use of all } \\
\text { complex of available } \\
\text { coercive measures. }\end{array}$ \\
\hline
\end{tabular}

Source: Korneeva and Gerasimov (2008) 
For drawing up the typology of situations of readiness, ability and desirability of changes in the organization the RWA model (readiness - wish - ability) and typology of the conflicts is used (Aistova 2002). A study of the staff relation to the changes includes a data set that is united in groups:

- General information about the organization and the employee;

- Assessment of emotional reaction of employees to the entered innovations;

- Assessment of the reasons for resistance to the changes by the employees;

- Assessment of degree of employees' knowledge on the plans of changes;

- Assessment of employees' opinion on degree of democratic character / authoritativeness of approach of the management at introduction of changes;

- Assessment of motivation for staff participation in changes;

- Assessment of employees' understanding of an essence of changes and a degree of trust to the persons who carry them out;

- Assessment of organization readiness for the changes;

- Assessment of desirability of the changes in the organization;

- Assessment of organization ability to the changes.

Only affirmative and negative answers are taken into account during assessment of a degree of employees' knowledge about the plans of changes (ADEK). For a definition of this indicator the following formula is used:

$$
A D E K=(m(+)-m(-)) /(m \times n)
$$

where $\mathrm{m}(+)$ - is quantity of affirmative answers;

$\mathrm{m}(-)$ - quantity of negative answers;

$\mathrm{n}$ - quantity of the questions which are contained in assessment;

$\mathrm{m}$ - quantity of participants of poll.

ADEK data are entered in a total form of assessment results. This indicator accepts value from 1 to -1 . The ADEK negative value confirms dissatisfaction of employees with degree of the knowledge of changes and serves as resistance reason.

Assessment of organization readiness for changes (ORCh), desirabilities of changes (DCh) and ability to changes $(\mathrm{ACh})$ is similar to the previous estimates and concretize a role of the head in management of the staff relation to the changes. Positive values of indicators testify to readiness, desirability and ability of the organization to implement the changes.

After carrying out a complex assessment and filling of a total form with results of assessment of the relation to the changes the working group can start to form MHR strategy.

For the assessment of efficiency of application of MHR strategy in the conditions of changes it is enough to reveal an extent of goal achievement, a ratio of the received indicators with planned and also the scale of positive changes of enterprise parameters concerning their initial state (Travin and Magura 2002).

The efficiency of MHR strategy can be considered from a position of three categories of participants in change management process: the initiators of the changes, the consultants and independent experts involved with administration and also from a position of employees. It is expedient to take a position of initiators of changes as they make the decision on creation of a control system of changes for a priority of efficiency assessment. Realization of MHR strategy allows to receive direct and perspective results.

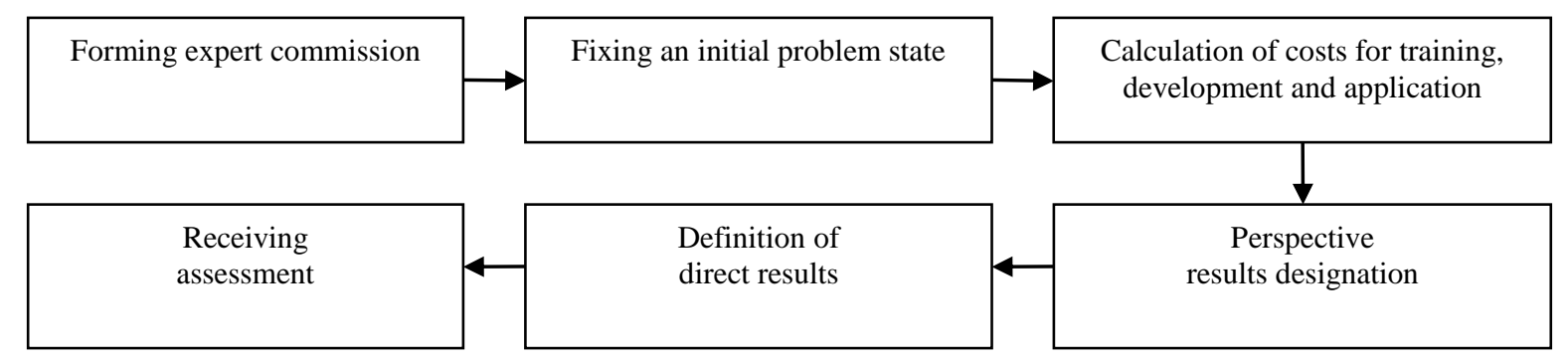

Fig. 1. Efficiency assessment of MHR strategy Source: Korneeva and Gerasimov (2008) 
Direct results are the ideas and solutions found in change management process, improvement of psychological climate in collective, decrease in level of resistance of personnel, tension recession, the positive relation to transformations, obtaining concrete knowledge, increase in professional motivation, overcoming steady stereotypes of thinking. Treat perspective results: formation of innovative organizational culture, ability to fast perception of innovations, improvement of indicators of technical and economic development, increase in financial stability, growth of capitalization and financial results.

In addition, one can see that MHR offers the following approach for determination of economic efficiency of strategy:

- to make a calculation of costs on use;

- to estimate perspective results from introduction;

- to carry out an assessment of direct results of realization;

- to compare the costs on use of model with the sum of assessment of direct and perspective results;

- to take the obtained data for an indicator of economic efficiency of using a technique of change management process. Assessment stages of efficiency of MHR strategy are presented in Figure 1 above.

The commission of experts has to consist of the managers competent of the questions of reforming and change management process. The large number of expert assessments will complicate processing of results, increase an expense of time and funds for efficiency assessment of MHR strategy, accounting of a small amount of experts' opinions will result in bias of assessment. It is offered to include in the commission from 3 to 5 experts having potentially various points of view. During fixing of an initial condition of a problem the definition of approaches to the efficiency assessment of MHR strategy is made. Calculation of costs for use of model has to include the salary of experts, payment of technical equipment, cost of materials, payment of consultants, etc.

Table 4. Assessment of effect from MHR strategy realization

\begin{tabular}{|c|c|c|}
\hline Assessment object & Result type & Ways and methods of assessment \\
\hline 1. Resistance to changes & $\begin{array}{l}\text { Reducing the level of staff } \\
\text { resistance, the decline in tension, } \\
\text { a positive attitude to change }\end{array}$ & $\begin{array}{l}\text { 1. Questionnaire survey of training } \\
\text { participants } \\
\text { 2. Model "force fields» }\end{array}$ \\
\hline 2. Reaction to changes & $\begin{array}{l}\text { Participants' opinion: like or not, } \\
\text { positive attitude, willingness to } \\
\text { apply the acquired knowledge, } \\
\text { increasing team cohesion, etc. }\end{array}$ & $\begin{array}{l}\text { 1.Evaluation questionnaire at the end } \\
\text { of events } \\
\text { 2. Surveys of participants }\end{array}$ \\
\hline $\begin{array}{l}\text { 3. Assimilation of } \\
\text { knowledge and skills }\end{array}$ & $\begin{array}{l}\text { - acquiring specific knowledge } \\
\text { - increase of professional } \\
\text { motivation } \\
\text { - overcoming the stereotypes of } \\
\text { thinking }\end{array}$ & $\begin{array}{l}\text { 1. Exams } \\
\text { 2. Tests } \\
\text { 3. Cases } \\
\text { 4. Digital measurements }\end{array}$ \\
\hline 4. Change of behavior & $\begin{array}{l}\text { Systematic application of } \\
\text { knowledge gained at the training } \\
\text { in the workplace }\end{array}$ & $\begin{array}{l}\text { 1. Included monitoring of the work of a } \\
\text { trained employee } \\
\text { 2. Conducting interviews }\end{array}$ \\
\hline 5. Effect & $\begin{array}{l}\text { The change of the results of the } \\
\text { company's activity: } \\
\text { Changes in quality indicators: } \\
\text { - increased customer satisfaction } \\
\text { - improvement of psychological } \\
\text { climate } \\
\text { - reduction of staff turnover } \\
\text { Changes in quantitative } \\
\text { indicators: } \\
\text { - sales volume } \\
\text { - rate of return } \\
\text { - profitability ratio, etc. }\end{array}$ & $\begin{array}{l}\text { 1. Personal observations of the } \\
\text { company's management } \\
\text { 2. The calculation of economic } \\
\text { indicators } \\
\text { 3. Custom research on the company's } \\
\text { image }\end{array}$ \\
\hline
\end{tabular}


Efficiency assessment includes a designation of set of perspective results and evaluating. Further a set of direct results of MHR strategy application is defined. The sum of expenses is subtracted from the total effect counted by direct and perspective results. The received result is accepted to an indicator of economic efficiency of MHR strategy use.

Complex efficiency assessment of measures is the long procedure in which a large number of employees is involved. The main problem of assessment is the lack of direct dependence between the realized strategy and change of quantitative business indicators. In the efficiency assessment of MHR strategy, it is enough to reveal effect of their influence on activity of the organization for various directions.

The four-level model of Kirkpatrick (1998) complemented with assessment of level of resistance to the changes (Table 4 above) is the basis for the efficiency assessment of MHR strategy.

At the first stage of the assessment it is advisable to determine the changes in staff resistance that occurred as a result of training. To do this, determine the level of staff resistance to the changes before and after the change management activities. The obtained preliminary assessment of the learning effect requires further research and clarification at the following levels.

At the second level, the response of staff to change management measures is determined. With the help of evaluation questionnaires and surveys of participants assess the attitude of employees, their opinion about the usefulness of change management measures in general, the willingness to apply the knowledge gained in the workflow. A positive result can be an increase in team cohesion.

At the level of assessment of acquired knowledge and skills, the emphasis is on determining the range of knowledge and skills, the level of professional motivation, the fact of overcoming stable stereotypes of participants' thinking. Various tests and examinations are used as methods for assessing the effect at this stage. In addition, it is possible to measure digitally the difference between the results of the previous and the results of the questionnaire following the activities to determine changes in the estimated parameters.

The rate of behavior change involves the assessment of systemic use resulting from the implementation of measures for change management in a workflow. This assessment can be obtained in the result of specialized interviews and participant observation of the work of the employees. It should be borne in mind that the method of observation is not always justified due to the negative reaction of staff to direct control of training results.

At the last and the most difficult level of assessment it is necessary to give a qualitative and quantitative assessment of changes in the company's performance. It is not possible to distinguish the impact of change management measures on performance from the influence of other factors, the proposed assessment has a high cost, so in practice it is enough to assess the first four levels with some elements of the fifth level.

The impact of training quality on the work of the company depends on the availability of working conditions necessary for the application of employees' knowledge and skills; on the organizational culture conducive to the application of new standards of work; on the quality of management. Well-designed and implemented change management measures may not be effective due to the lack of the necessary conditions for their application. For example, a situation in which the event was attended by a minority of employees can lead to the fact that the contestants are in isolation, not being understood by others, not undergone such training of employees.

The method of assessing the effectiveness of change management technologies can be used as a basis for decision-making on the use of these technologies, as a means of evaluating the effectiveness of the educational process, as a tool for feedback from managers and specialists.

\section{Conclusions}

Overall, one can conclude that leaders play a crucial role in initiating and implementing changes, as they initiate strategic changes aimed at strengthening and developing the organization; they are responsible for developing a strategy for changes and planning activities for their implementation. They formulate the vision and "show the goods with face", help the employees to see the "picture of changes and consequences" in general, strive to create a continuously learning organization and employees, prepare them to solve complex problems. To manage the process of change, despite the resistance of the staff, the manager needs to have clear goals of changes embedded in the development strategy of the enterprise, to imagine the stages of implementation of changes, to "recruit" supporters, to consider special "motivating" employees of the event and to understand that, starting the process of change, he/she has to go to the end.

Through conducting various changes, the leaders hope that the organization will develop itself and employees will work even more effectively. Overcoming the resistance, the manager should set new guidelines which the employee can perceive as motivating for new actions. It should be borne in mind that work on changes in the organization is a constant and consistent work with the motivation of employees. 


\section{References}

Aistova M, Enterprise restructuring: Management issues. Strategies, coordination of structural parameters, reduction of resistance to transformation, $1^{\text {st }}$ edn. (Moscow: Alpina Publishing, 2002), 287 p.

Alekhina O (2004) Change management: helping the organization to acquire new skills. Management Today 5: 43-46.

Ansoff I, New corporate strategy, $1^{\text {st }}$ edn. (Saint Petersburg: PiterCom. 1999), 416 p.

Čábelková I, Abrhám J, Strielkowski W (2015) Factors influencing job satisfaction in post-transition economies: the case of the Czech Republic. International Journal of Occupational Safety and Ergonomics 21(4):448-456. doi: 10.1080/10803548.2015.1073007

Duck JD, Monster of change. The reasons for the success and failure of organizational change, $1^{\text {st }}$ edn. (Moscow: Alpina Publishing, 2002), 320 p.

Erokhin D (2002) On the issue of staff attitude management to changes in the management system of industrial enterprises. Management in Russia and Abroad (4):78-83.

Kirkpatrick D, Evaluating training programs: the four levels, $1^{\text {st }}$ edn. (San Francisco: Berrett-Koehler Publishers. Inc. 1998), 289 p.

Kleiner G (2007) System paradigm and economic policy. Social Sciences and modernity 2:50-58.

Korneeva E, Gerasimov B, Change management in enterprises, $1^{\text {st }}$ edn. (Togliatti: VU Publishing, 2008), 148 p.

Korneeva E (2016) Ways of improving the comprehensive staff management system in service companies. Bulletin of the Volga State University of Service. Series: Economy 1(43):116-123.

Korchagin P, Korneeva E, Nikitina N (2015) Factors that influence the effectiveness of Russian telecommunication companies. Economics \& Sociology 8(3):119-130. doi: 10.14254/2071-789x.2015/8-3/9

Krayneva R, Bugaev A, Zhuravleva T, Vojtovič S (2017) Management and promotion of economic innovation potential. Journal of International Studies 10(1): 146-158. doi: 10.14254/2071-8330.2017/10-1/10

Martell K, Carroll S (1995) How Strategic is Human Resource Management? Human Resource Management 2(34): 253-267. doi: 10.1002/hrm.3930340203

Milner B (2006) Concept of organizational changes in modern companies. Problems of management theory and practice 1:27-34.

Moskalenko V, Yevsieieva I (2015) Effective leadership conflict management in food technology enterprises. International Economics Letters 4(2):91-102. doi: 10.24984/iel.2015.4.2.4

Narkunienè J, Ulbinaitė A (2018) Comparative analysis of company performance evaluation methods. Entrepreneurship and Sustainability Issues 6(1):125-138. doi:10.9770/jesi.2018.6.1(10)

Niño-Amézquita J, Dubrovsky V, Jankurová A (2017) Innovations and competitiveness in regional development: a comparison of Latin America, Europe, and China. Czech Journal of Social Sciences, Business and Economics 6(1):28-36. doi: 10.24984/cjssbe.2017.6.1.4

Plenkina V, Andronova I, Deberdieva E, Lenkova O, Osinovskaya I (2018) Specifics of strategic managerial decisions-making in Russian oil companies. Entrepreneurship and Sustainability Issues 5(4):858-874. doi:10.9770/jesi.2018.5.4(11)

Purcell J (1999) Best practice or best fit: chimera or cul-de-sac. Human Resource Management Journal 9(3):2641. doi: 10.1111/j.1748-8583.1999.tb00201.x

Sisson K (1993) In search of HRM. British Journal of Industrial Relations 31(2):201-210. doi: 10.1111/j.14678543.1993.tb00389.x

Strielkowski W, Shishkin A, Galanov V (2016) Modern management: beyond traditional managerial practices. Polish Journal of Management Studies 14(2):225-231. doi: 10.17512/pjms.2016.14.2.21

Travin V, Magura M (2002) Staff consulting in the context of organizational changes. Staff Management 6:2534. 